\title{
ANALISIS MARJIN PEMASARAN DAGING SAPI DI PASAR-PASAR TRADISIONAL KOTA MEDAN
}

\author{
(Analysis of Marketing Margin of Beef in Traditional Markets in Medan)
}

\author{
Edy Suherman ${ }^{1}$, Edhy Mirwandhono² dan Armyn Hakim Daulay ${ }^{3}$ \\ 1. Mahasiswa Program Studi Peternakan Fakultas Pertanian Universitas Sumatera Utara \\ 2. Staff Pengajar Program Studi Peternakan Fakultas Pertanian Universitas Sumatera Utara
}

\begin{abstract}
This study aimed to determine the systematic distribution of beef from the producer until to consumer. The experiment was conducted at feedlot, at slaughter house and traditional market in Medan on April 2014 to May 2014. The research used survey method with 7 traditional markets and 35 respondents. Primary data were obtained from the beef sellers in the traditional marketing Medan, while the secondary data obtained from various relevant agencies, such as the central institution of statistics and the slaughter house Mabar and slaughter TaniAsli. The parameters studied were marketing margin of the beef. There are two types of marketing channels contained in the marketing process of beef from the producer until to consumer. The first channel was producer - wholesaler retailer-consumer and the second channel was producer-agent-wholesaler-consumer. Marketing margin at the wholesalers were Rp. 3.311 million/head and at the retailers were Rp. 1.992 million/head. The conclusion is the shorter market chain have higher marketing margin on wholesaler. This suggests that the best marketing channel for beef seller was the second channel that is: producer - agent-wholesaler - consumer.
\end{abstract}

Keywords :Marketing margin, beef, traditional markets in Medan

\begin{abstract}
ABSTRAK
Penelitian ini bertujuan untuk mengetahui sistematis penyaluran daging sapi dari Produsen hingga sampai ke konsumen akhir. Penelitian dilaksanakan di beberapa perusahaan penggemukan, pasar tradisional kota Medan dan di rumah potong hewan Mabar dan rumah potong hewan Tani asli pada bulan April sampai dengan Mei 2014. Metode penelitian yang digunakan adalah metode survey dengan 7 pasar tradisional dan 35 responden. Data primer diperoleh dari para penjual daging sapi di pasar tradisional kota Medan, sedangkan data sekunder diperoleh dari berbagai instansi yang terkait, seperti badan pusat statistik dan rumah potong hewanMabar dan rumah potong hewan Tani Asli. Parameter yang diteliti adalah marjin pemasaran daging sapi. Ada dua jenis saluran pemasaran yang terdapat dalam proses pemasaran daging sapi dari produsen hingga sampai ke konsumen. Saluran pertama produsen - pedagang besar- pedagang pengecer -konsumen dan saluran kedua produsen - agen - pedagang besar konsumen. Margin pemasaran pada pedagang besar adalah sebesar Rp. 3.311.000,-/ekor sapi dan pada pedagang kecil adalah sebesar sebesar Rp. 1.992.000,-/ekor sapi. Kesimpulannya adalah saluran pemasaran yang lebih pendek memiliki marjin pemasaran yang lebih besar bagi pedagang besar. Ini menunjukkan bahwa saluran pemasaran daging sapi yang baik bagi pedagang sapi adalah adalah saluran kedua yaitu : Produsen - agen - pedagang besar konsumen.
\end{abstract}

Kata kunci : Marjin pemasaran, daging sapi, pasar tradisional, kota Medan 


\section{PENDAHULUAN}

Daging sapi sebagai sumber protein yang berasal dari ternak hewan sudah dikenal sebagai bahan pangan yang hampir lengkap dan sempurna. karena didalamnya terkandung berbagai macam zat gizi yang diperlukan tubuh termasuk didalamnya protein hewani. Indonesia sebagai salah satu negara dengan jumlah penduduk terbesar keempat di dunia memiliki tingkat konsumsi protein yang masih relatif rendah dibanding negara lain, terutama dari daging sapi. Setiap 100 gram daging sapi mengandung protein sebesar 18,8 gram. Protein ini memiliki struktur asam amino yang sangat baik untuk tubuh seperti membantu pertumbuhan pada anak, memperbaiki sel-sel yang rusak, sebagai bahan pembentuk plasma kelenjar, sebagai cadangan energy serta dengan mengkonsumsi daging sapi dapa tmenjaga keseimbangan asam basa darah. Adapun kandungan gizi yang terdapat pada setiap 100 gram daging sapi yaitu kalori : 207,0 kkal, protein : 18,8 gram, lemak : 14,0 gram, kalsium : 11,0 mg, phosphor : 170,0 mg, besi : 2,8 mg (Syakur, 2012).

Konsumsi daging sapi di Indonesia masih tergolong rendah jika dibandingkan dengan negara - negara lainnya. Dari sekitar 220 juta jiwa penduduk Indonesia, konsumsi daging per kapita hanya $1,8 \mathrm{~kg}$ per tahun. Jauh lebih rendah jika dibandingkan dengan Filiphina dan Malaysia yaitu masing-masing sebesar $7 \mathrm{~kg}$ per kapita/tahun dan $15 \mathrm{~kg}$ per kapita/tahun. Namun seiring dengan peningkatan jumlah penduduk, pertumbuhan ekonomi, dan pendidikan yang semakin baik, maka meningkat pula permintaan daging sapi di Indonesia. Indonesia dengan jumlah penduduknya pada tahun 2007 yang mencapai sekitar 220 juta jiwa, total permintaan daging sapi domestik berarti mencapai 384.810 ton. Badan Penelitian dan Pengembangan Pertanian (2005) menyatakan, total produksi daging sapi dalam negeri hanya mencapai 271.840 ton atau 70,64 persen, sehingga masih ada kekurangan sekitar 112.970 ton atau 29,36 persen dari total kebutuhan dalam negeri. Kekurangan tersebut dipenuhi dengan melakukan impor.

Rendahnya konsumsi daging di Indonesia, khususnya daging sapi disebabkan oleh beberapa faktor. Misalnya kesadaran masyarakat akan pentingnya mengkonsumsi daging yang masih sangat rendah dan harga daging sapi itu sendiri yang tinggi atau mahal (Daslina, 2002). Tingginya harga daging sapi di pasar-pasar tradisional disebabkan oleh beberapa faktor, yaitu: 1) harga sapi hidup dari para pengusaha atau peternak yang masih sangat tinggi, 2) berkurangnya jumlah pasokan daging sapi dan 3) naiknya harga BBM belakangan ini sehingga menyebabkan harga daging sapi pun meningkat. Menurut data terbaru dari harian Kompas (2013), di beberapa pasar tradisional Kota Medan terjadi perbedaan harga daging 
sapi di tiap penjualnya. Harga daging sapi tersebut berkisar antara Rp. 65.000,-/kg sampai Rp. $85.000,-/ \mathrm{kg}$.

Belum diketahui pasti apa penyebab perbedaan harga daging sapi di masing-masing penjual tersebut. Untuk itu, perlu dilakukan penelitian mengenai analisis harga daging sapi di pasar- pasar tradisional kota Medan, sehingga dapat diketahui berapa marjin harga daging sapi dari tingkat produsen hingga sampai ke konsumen akhir dandapat pula diketahui jenisjenis saluran pemasaran daging sapi di Kota Medan.

\section{BAHAN DAN METODE PENELITIAN}

\section{Tempat dan Waktu Penelitian}

Penelitian ini dilaksanakan di beberapa pasar tradisional Kota Medan, yaitu: pasar Pagi Setia Budi, pasar Sei Skambing, pasar Sambu (Sentral), pasar Brayan, pasar Pringgan, pasar Simpang Limun dan pasar Kampung Lalang sertadi Rumah Potong Hewan Mabar. Penelitian dliaksanakan pada bulan Maret 2014 sampai Mei 2014.

\section{Metode Penelitian}

1. Penentuan responden dan analisis harga daging

Responden terdiri dari para penjual daging di pasar-pasar tradisional kota Medan. Metode penelitian yang digunakan adalah metode survey dengan unit responden yang menjual daging sapi. Responden berasal dari 7 pasar tradisional yang dipilih secara acak dari 21 Kecamatan yang terdapat di Kota Medan (masing-masing Kecamatan terdiri dari 1 pasar), tiap pasar terdiri dari 5 orang penjual daging sapi. Dari masing-masing pasar, responden dipilih secara accidental sampling yaitu responden yang ada pada saat didatangi ke pasar dan bersedia untuk diwawancarai serta memiliki data yang diperlukan (Khoirunnisa, 2008).

\section{Pengumpulan Data}

Data yang dikumpulkan pada penelitian in terdiri dari data primer dan data sekunder.

1. Data primer diperoleh dari pengumpuan data terhadap para penjual daging sapi di pasar-pasar tradisional kota Medan.

2. Data sekuder diperoleh dari berbagai instansi yang terkait, seperti Badan Pusat Statistik dan Rumah Potong Hewan (RPH) Mabar. 


\section{Metode Analisis Data}

1. Saluran dan lembaga tataniaga

Pola dan lembaga tataniaga yang terlibat dalam tataniaga daging sapi dapat diketahui melalui wawancara langsung terhadap produsen daging sapi dan lembaga tataniaga yang terlibat didalamnya. Analisis data saluran dan lembaga tataniaga secara deskriptif analisis.

2. Margin tataniaga (Sudiyono, 2001)

Rumus :

$$
\mathrm{M}=\mathrm{Hk}-\mathrm{Hp}
$$

Keterangan :

$\mathrm{M}=$ Margin tataniaga $\quad \mathrm{Hk}=$ Harga tingkat konsumen

$\mathrm{Hp}=$ Harga tingkat produsen

\section{Efisiensi Tataniaga}

Menurut Shepherd dalam Soekartawi (1989) menuliskan bahwa, efisiensi tataniaga adalah nisbah antara total biaya dengan total nilai produk yang dipasarkan, atau dapat dirumuskan :

$$
\mathrm{EPs}=(\mathrm{TB} / \mathrm{TNP}) \times 100 \%
$$

Keterangan :

EPs $=$ Efisiensi tata niaga

$\mathrm{TB}=$ Total biaya pemasaran

TNP = Total nilai produk

\section{HASIL DAN PEMBAHASAN}

\section{Karakteristik Responden}

Karakteristik responden (pedagang daging sapi) di pasar-pasar tradisional Kota Medan dari 35 pedagang tersebut dapat dilihat bahwa ada 3 orang yang berperan sebagai agen dan 32 orang berperan sebagai pedagang pengecer. Dari data tersebut terlihat bahwa pedagang daging sapi di pasar-pasar tradisional Kota Medan mempunyai umur yang bervariasi yaitu antara 17 - 55 tahun dengen tingkat pendidikan rata-rata tamat SMA, sedangkan jumlah daging sapi yang dijual berkisar antara 300 - $1000 \mathrm{~kg} / \mathrm{hari}$. Dilihat dari pengalaman berdagang hanya ada 7 orang yang memiliki pengalaman kurang dari 5 tahun. Rata-rata tanggungan keluarga responden yaitu 3 orang. 


\section{Saluran dan Lembaga Pemasaran Daging Sapi}

Menurut Kotler (2002), saluran tataniaga adalah serangkaian lembaga yang melakukan semua fungsi yang digunakan untuk menyalurkan produk dan status kepemilikannya dari produsen ke konsumen. Proses penyaluran hasil produksi merupakan bagian yang tidak terpisahkan dalam proses produksi barang oleh suatu perusahaan atau industri. Berdasarkan hasil penelitian dan wawancara dengan 35 responden pedagang daging sapi di pasar-pasar tradisional serta responden yang berasal dari perusahaan Feedlot (penggemukan sapi) diketahui ada 2 macam saluran pemasaran dari produsen hingga sampai ke konsumen akhir. Kedua saluran pemasaran tersebut adalah sebagai berikut:

\section{a. Saluran Pertama}

Saluran pemasaran daging sapi dari produsen hingga sampai ke konsumen akhir dapat dilihat pada diagram berikut ini:

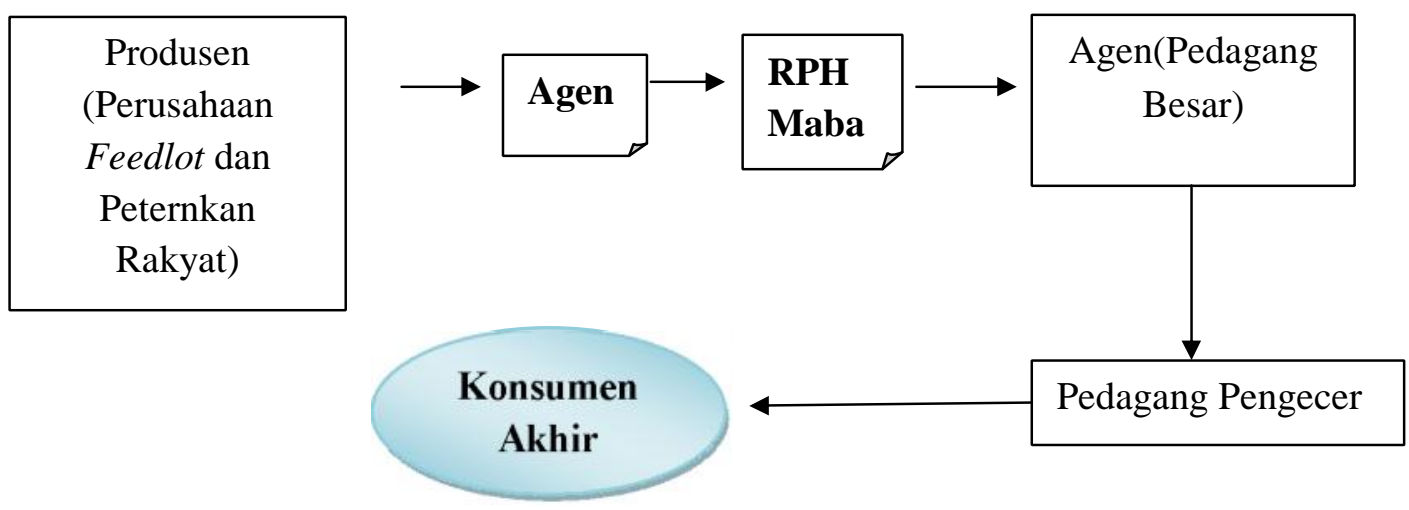

Gambar 1. Diagram Penyaluran (Pemasaran) Daging Sapi dari Produsen Hingga Sampai ke Konsumen Akhir (Data primer penelitian, 2014).

Saluran pemasaran ini paling banyak dilakukan oleh para pelaku pasar produk daging sapi di pasar-pasar tradisional Kota Medan.Sapi-sapi dari Produsen (Feedlot) akan langsung didistribusikan ke para pedagang besar (agen). Kemudian Agen akan menjual kepada pedagang eceran (pengecer) dalam bentuk daging, tulang, lemak (cincang), jeroan dan lain-lain (bentuk siap konsumsi). Selanjutnya daging-daging sapi tersebut akan dijual oleh pengecer kepada konsumen akhir (masyarakat).

Produsen merupakan perusahaan penggemukan sapi (Feedlot) dan peternakan rakyat yang mendistribusikan sapi-sapi import maupun lokal kepada pedagang besar (agen) di seluruh Kota Medan. Di RPH Mabar, ada 3 produsen yang berperan dalam proses pemasaran 
daging sapi yaitu dapat dilihat pada Tabel 5. PT. Lembu Andalas Langkat dan PT. Eldira Fauna Asahan merupakan perusahaan peternakan yang menyediakan sapi potong jenis import yang berasal dari Australia. Setiap harinya ada sekitar $7-8$ ekor sapi yang didistribusikan perusahaan tersebut ke para Agen daging sapi yang melakukan proses penyembelihan di RPH Mabar. Harga daging sapi yang mereka tawarkan kepada para agen adalah Rp. 37.500,- sampai Rp. 38.000,- per kilogram bobot hidup. Penetuanharga bobot hidup daging sapi tersebut ditentukan oleh 2 faktor, yaitu:

1) Jenis kelamin

Sapi betina memiliki harga jual yang lebih rendah dibandingkan dengan sapi jantan. Sapi betina dijual dengan harga Rp. 37.500,- per kilogram bobot hidup, sedangkan sapi jantan dijual dengan kisaran harga Rp. 37.700,- sampai Rp. 38.000,- per kilogram bobot hidup.

2) Jenis sapi (pengelompokkan sapi disini dikhususkan pada sapi jantan)

Sapi jantan yang tidak dikastrasi (Bull) dijual dengan harga Rp. 38.000,- per kilogram bobot hidup sedangkan sapi jantan yang dikastrasi (Steer) dijual dengan harga Rp. 37.700,- per kilogram bobot hidup.

Tabel 1. Perusahaan-perusahaan penggemukan sapi (produsen daging sapi) di Kota Medan yang mendistribusikan produknya ke RPH Mabar

\begin{tabular}{|c|c|c|c|}
\hline No & $\begin{array}{l}\text { Nama Perusahaan } \\
\text { (Feedlot })\end{array}$ & $\begin{array}{c}\text { Jumlah sapi yang } \\
\text { didistribusikan ke } \\
\text { RPH/hari }\end{array}$ & $\begin{array}{c}\text { Harga Sapi/kg Bobot } \\
\text { Hidup }\end{array}$ \\
\hline 1 & $\begin{array}{l}\text { PT. Lembu Andalas } \\
\text { Langkat }\end{array}$ & 7 - 8 ekor & $\begin{array}{l}\text { Rp. 37.500,- sampai } \\
\text { Rp. } 38.000,-\end{array}$ \\
\hline 2 & $\begin{array}{l}\text { PT. Eldira Fauna } \\
\text { Asahan }\end{array}$ & 7 - 8 ekor & $\begin{array}{l}\text { Rp. 37.500,- sampai } \\
\text { Rp. 38.000,- }\end{array}$ \\
\hline 3 & Peternakan Rakyat & 5 ekor & $\begin{array}{l}\text { Rp. } 37.500,- \text { sampai } \\
\text { Rp. } 38.000,-\end{array}$ \\
\hline
\end{tabular}

Sumber: Data sekunder penelitian (April, 2014)

Tabel 2. Perusahaan-perusahaan penggemukan sapi (produsen daging sapi) di Kota Medan yang mendistribusikan produknya ke RPH TaniAsli.

\begin{tabular}{|c|c|c|c|}
\hline No & $\begin{array}{l}\text { Nama Perusahaan } \\
\text { (Feedlot })\end{array}$ & $\begin{array}{c}\text { Jumlah sapi yang } \\
\text { didistribusikan ke } \\
\text { RPH/hari }\end{array}$ & $\begin{array}{c}\text { Harga Sapi/kg Bobot } \\
\text { Hidup }\end{array}$ \\
\hline 1 & $\begin{array}{l}\text { PT. Lembu Andalas } \\
\text { Langkat }\end{array}$ & $5-6$ ekor & $\begin{array}{l}\text { Rp. } 37.500,- \text { sampai } \\
\text { Rp. } 38.000,-\end{array}$ \\
\hline 2 & $\begin{array}{l}\text { PT. Eldira Fauna } \\
\text { Asahan }\end{array}$ & 3 - 5 ekor & $\begin{array}{l}\text { Rp. } 37.500,- \text { sampai } \\
\text { Rp. } 38.000,-\end{array}$ \\
\hline 3 & Peternakan Rakyat & 3 ekor & $\begin{array}{l}\text { Rp. } 37.500,- \text { sampai } \\
\text { Rp. } 38.000,-\end{array}$ \\
\hline
\end{tabular}

Sumber: Data sekunder penelitian (April, 2014) 
Rumah pemotongan hewan dalam hal ini berperan sebagai lembaga yang menyediakan jasa tempat pemotongan. Semua sapi-sapi dari perusahaan Feedlot dan dari peternakan rakyat harus disembelih di RPH. Setelah sapi-sapi tersebut selesai disembelih baru kemudian dapat didistribusikan (dijual) oleh agen kepada para pedagang eceran di seluruh pasar-pasar tradisional Kota Medan. Hal ini sesuai dengan Peraturan Pemerintah Republik Indonesia No. 95 Tahun 2012 yang tertulis pada Bab II Paragraf 5 Pasal 8 (1), dengan bunyi sebagai berikut: Pemotongan hewan potong yang dagingnya diedarkan harus dilakukan di Rumah Potong Hewan yang:(a) memenuhi persyaratan teknis yang diatur oleh Menteri; dan (b) menerapkan cara yang baik.

Semua Agen akan dikenakan biaya retribusi oleh pihak RPH untuk jasa tempat pemotongan yang diberikan. Daftar biaya retribusi yang harus dikeluarkan agen ditentukan berdasarkan jenis ternaknya. Biaya retribusi tertera dalam Tabel 3.

Tabel 3. Biaya retribusi yang dikeluarkan oleh agen kepada rumah potong hewan

\begin{tabular}{clc}
\hline No & Jenis hewan yang disembelih & Biaya retribusi (Rp/ekor) \\
\hline 1 & Sapi: & \\
& a. Sapi impor & 85.000 \\
& b. Sapi lokal & 65.000 \\
2 & Kerbau & 85.000 \\
3 & Kambing dan Domba & 40.000 \\
4 & Babi & 55.000 \\
\hline
\end{tabular}

Sumber: Data sekunder penelitian (April, 2014)

b. Saluran Kedua

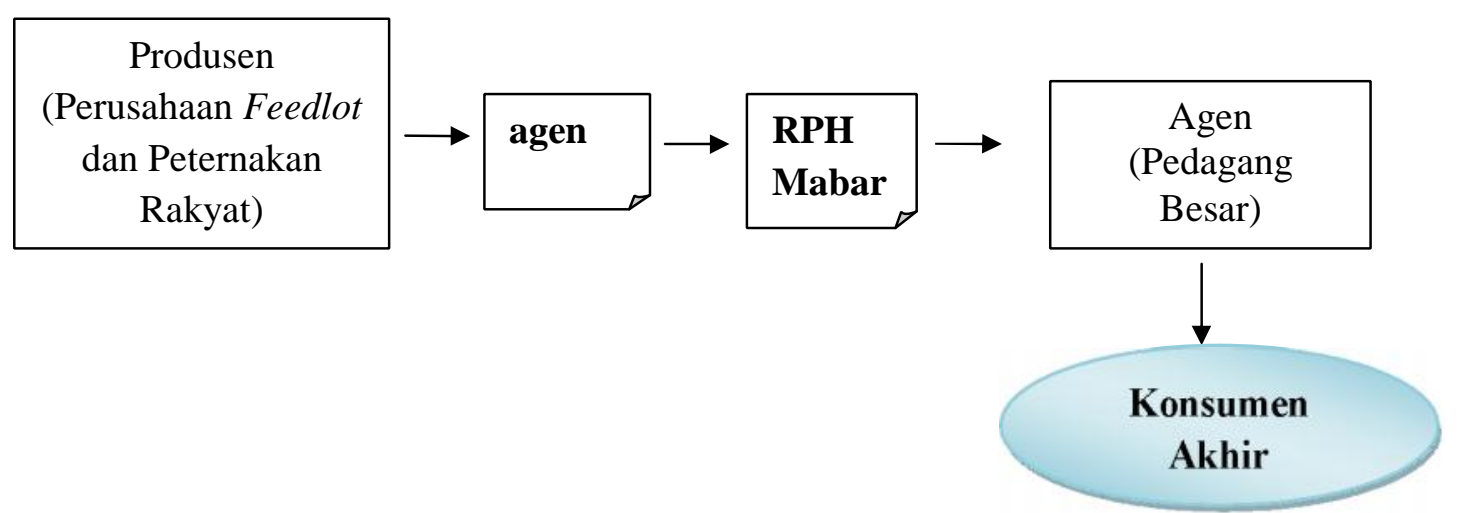

Gambar 2. Diagram penyaluran (pemasaran) daging sapi dari produsen hingga sampai ke konsumen akhir.

Saluran pemasaran ini, pedagang besar (agen) langsung memasarkan daging sapi kepada konsumen akhir tanpa perantara pedagang pengecer. Para pedagang besar juga menjual daging sapi di pasar-pasar tradisional Kota Medan seperti halnya yang dilakukan 
oleh pedagang pengecer. Jadi, agen sekaligus berperan ganda dalam memasarkan daging sapi. Pertama, agen berperan sebagai pedagang besar yang menyalurkan (menjual) daging sapi ke para pedagang pengecer. Kedua, agen bertindak sebagai pedagang pengecer yang menjual daging sapi langsung kepada konsumen akhir (masyarakat).

Harga penjualan daging antara pedagang besar dan pedagang pengecer hampir tidak ada perbedaannya, hanya saja pedagang besar menjual lebih banyak jenis produk yang berasal dari ternak sapi. Jenis produk yang ditawarkan (dijual) pedagang besar dan eceran dapat dilihat pada Tabel 4 berikut ini.

Tabel 4. Jenis-Jenis Produk yang Dijual oleh Pedagang Besar dan Pedagang Pengecer di Pasar-Pasar Tradisional Kota Medan

\begin{tabular}{clcc}
\hline No & \multicolumn{1}{c}{ Jenis Produk yang Dijual } & $\begin{array}{c}\text { Pedagang Besar } \\
\text { (agen) }\end{array}$ & $\begin{array}{c}\text { Pedagang } \\
\text { Pengecer }\end{array}$ \\
\hline 1 & Daging Sapi: & $\checkmark$ & \\
& a. Daging kelas A & $\checkmark$ & $\checkmark$ \\
& b. Daging Kelas B & $\checkmark$ & $\checkmark$ \\
2 & Tulang Iga Super & $\checkmark$ & - \\
3 & Tulang Kaki & $\checkmark$ & - \\
4 & Tulang biasa & $\checkmark$ & $\checkmark$ \\
5 & Lemak (cincang) & $\checkmark$ & $\checkmark$ \\
6 & Kikil (badan dan kuping) & $\checkmark$ & - \\
7 & Kikil Kaki & $\checkmark$ & $\checkmark$ \\
8 & Jeroan selain hati ( usus, paru, babat) & $\checkmark$ & - \\
9 & Otak & $\checkmark$ & - \\
10 & Ekor & & \\
\hline
\end{tabular}

Sumber: Data sekunder penelitian (April, 2014)

Tabel 5 menjelaskan bahwa pedagang pengecer hanya menjual (menyediakan) beberapa jenis produk saja dari seekor ternak sapi, seperti: daging kelas A dan kelas B, cincang, kikil, serta jeroan selain hati. Sedangkan pedagang besar menjual semua jenis daging dan tulang.

\section{Biaya Pemasaran}

Biaya pemasaran yang dianalisis adalah biaya pemasaran yang dikeluarkan responden selama proses pemasaran produk (daging sapi) berlangsung. Biaya pemasaran daging sapi pada setiap lembaga pemasaran dapat dilihat pada Tabel 5. Tabel tersebut menjelaskan bahwa seorang pedagang besar (agen) harus mengeluarkan biaya pemasaran 
dengan rata-rata Rp. 185.000,- per ekor sapi yang disembelih dan dijual ke pasar tradisional, sedangkan pedagang pengecer tidak mengeluarkan biaya apapun dalam proses pemasaran daging sapi.

Tabel 5. Biaya pemasaran daging sapi pada setiap lembaga pemasaran per hari

\begin{tabular}{llcccc}
\hline No & $\begin{array}{c}\text { Lembaga } \\
\text { Pemasaran }\end{array}$ & $\begin{array}{c}\text { Biaya } \\
\text { Transportasi } \\
(\text { Rp/hari) }\end{array}$ & $\begin{array}{c}\text { Biaya } \\
\text { Retribusi } \\
\text { (Rp/hari) }\end{array}$ & $\begin{array}{c}\text { Biaya Sewa } \\
\text { Kios (Rp/hari) }\end{array}$ & Total Biaya \\
\hline 1 & $\begin{array}{l}\text { Pedagang } \\
\text { besar } \\
\text { (agen) }\end{array}$ & 100.000 & 85.000 & 55.000 & 240.000 \\
2 & $\begin{array}{l}\text { Pedagang } \\
\text { pengecer }\end{array}$ & 10.000 & - & 27.000 & 37.000 \\
\hline
\end{tabular}

Sumber: Data sekunder penelitian (April, 2014)

\section{Margin Pemasaran Daging Sapi}

Margin pemasaran daging sapi dapat dilihat dari perbandingan harga daging sapi mulai dari produsen hingga sampai ke konsumen akhir. Rincian harga daging sapi dapat dilihat pada Tabel 6. Harga daging sapi yang dijual pada konsumen akhir adalah Rp. $100.000,-/ \mathrm{kg}$ untuk daging kelas A dan Rp. 90.000,-/kg untuk dagingkelas B. Harga tersebut berlaku bagi pedagang besar dan pengecer. Harga dari pedagang besar untuk pedagang pengecer biasa dikenal dengan istilah "harga tolak". Untuk melihat saluran distribusi yang lebih efektif pada suatu pemasaran dapat diketahui dari margin pemasaran pada tiap-tiap pelaku pasar.

Tabel 6 menunjukkan bahwa saluran pertama memiliki margin pemasaran yang besar yaitu harga beli sapi dari produsen sebesar Rp. 17.499.000,- dan menjualnya ke konsumen akhir dengan total harga Rp. 20.810.000,-. Semakin kecil nilai margin pemasaran suatu produk, maka akan semakin baik saluran pemasaran tersebut. Hal ini sesuai dengan pernyataan Rasuli, et. al. (2007), dalam penelitiannya menyatakan bahwa lembaga pemasaran telur itik dengan margin Rp. 100,-/butir lebih baik dibandingkan dengan lembaga pemasaran yang marginnya Rp. 150,-/butir. Margin pemasaran daging sapi di dapat dilihat pada Tabel 7. 
Tabel 6. Perincian rataan harga daging sapi pada berbagai lembaga pemasaran

\begin{tabular}{|c|c|c|c|c|c|}
\hline \multirow[b]{2}{*}{ No } & \multirow[b]{2}{*}{$\begin{array}{c}\text { Jenis Produk yang } \\
\text { Dijual }\end{array}$} & \multirow[b]{2}{*}{$\begin{array}{l}\text { Produsen } \\
(\mathrm{Rp} / \mathrm{kg})\end{array}$} & \multicolumn{2}{|c|}{ Pedagang Besar (Rp/kg) } & \multirow[b]{2}{*}{$\begin{array}{c}\text { Pedagang } \\
\text { Pengecer } \\
(\mathrm{Rp} / \mathrm{kg})\end{array}$} \\
\hline & & & $\begin{array}{c}\text { Harga untuk } \\
\text { Pengecer } \\
\text { (harga tolak) }\end{array}$ & $\begin{array}{c}\text { Harga untuk } \\
\text { konsumen } \\
\text { akhir }\end{array}$ & \\
\hline 1 & Daging Sapi: & & & & \\
\hline & a. Daging kelas A & 87.000 & 90.000 & 100.000 & 100.000 \\
\hline & b. Daging Kelas B & 87.000 & 88.000 & 90.000 & 90.000 \\
\hline 2 & Tulang Iga Super & 25.000 & 55.000 & 60.000 & \\
\hline 3 & Tulang Kaki* & 20.000 & 25.000 & 30.000 & \\
\hline 4 & Tulang biasa & 25.000 & 27.000 & 35.000 & \\
\hline 5 & $\begin{array}{l}\text { Lemak (cincang) } \\
\text { Kikil (badan dan }\end{array}$ & 18.000 & 25.000 & 30.000 & 30.000 \\
\hline 6 & kuping) & 20.000 & 22.000 & 30.000 & 30.000 \\
\hline 7 & $\begin{array}{l}\text { Kikil Kaki } \\
\text { Jeroan selain hati }\end{array}$ & 24.000 & 26.000 & 35.000 & \\
\hline 8 & (usus, paru, babat) & 28.000 & 32.000 & 40.000 & 40.000 \\
\hline 9 & Otak & 15.000 & 23.000 & 30.000 & \\
\hline 10 & Ekor & 42.000 & 50.000 & 60.000 & \\
\hline
\end{tabular}

Tabel 6. Rincian rataan harga daging sapi per kilogram

Ket : *=tulang kaki dijual perbuah

Sumber: Data sekunder penelitian (April, 2014)

Tabel 7 . Margin pemasaran daging sapi pada setiap lembaga pemasaran

\begin{tabular}{clccc}
\hline No & Lembaga Pemasaran & $\begin{array}{c}\text { Harga Beli } \\
(\mathrm{Rp})\end{array}$ & $\begin{array}{c}\text { Harga Jual } \\
(\mathrm{Rp})\end{array}$ & $\begin{array}{c}\text { Margin } \\
\text { Pemasaran } \\
(\mathrm{Rp})\end{array}$ \\
\hline 1 & Pedagang besar & 17.499 .000 & 20.810 .000 & 3.311 .000 \\
2 & Pedagang pengecer & 18.818 .000 & 20.810 .000 & 1.992 .000 \\
\hline Ket & : Harga dihitung dengan ukuran satu ekor sapi & & \\
Sumber: & Data sekunder penelitian (April, 2014)
\end{tabular}

\section{KESIMPULAN}

Margin pemasaran daging sapi tertinggi yang diterima lembaga pemasaran yaitu pada pedagang besar (agen) sebesar Rp. 3.311.000,-/ ekor sapi dan yang terendah terdapat pada pedagang pengecer yaitu sebesar Rp. 1.192.000,-/ ekorsapi. Ini menunjukkan bahwa saluran pemasaran daging sapi di pasar - pasar tradisional Medan yang terbaik bagi pedagang daging sapi adalah saluran kedua yaitu: Produsen - agen - Pedagang besar - Konsumen. 


\section{DAFTAR PUSTAKA}

Badan Penelitian dan Pengembangan Pertanian. 2005. Prospek dan Arah Pengembangan Agribisnis: Rangkuman Kebutuhan Investasi. Departemen Pertanian Republik Indonesia, Jakarta.

Daslina, 2002. Analisis Permintaan Daging Sapi, Kerbau, Kambing, Ayam Ras, dan Ayam Buras di Kabupaten Bogor. Skripsi. Jurusan Sosial Ekonomi Industri Peternakan Fakultas Peternakan, IPB, Bogor.

Harian KOMPAS. 2013. Medan. Edisi 23 September 2013.

Khoirunnisa, 2008. Analisis Permintaan Daging Ayam Broiler Konsumen Rumah Tangga di Kecamatan pancoran Mas Kota depok. Skripsi. Program Studi Sosial Ekonomi Peternakan Fakultas Peternakan, IPB, Bogor.

Kotler, P., 2002. ManajemenPemasaran. Edisi Indonesia.Dalam: Firdaus, M.S., 2010. SkripsiFakultasEkonomiGunadarma, Depok.

Soekartawi, 1993. Manajemen Pemasaran Hasil Pertanian, Teori dan Aplikasinya. Rajawali, Jakarta.

Syakur, 2012. Daging Sapi Sehat Bermanfaat Bagi Tubuh. Dalam: Tataniaga Daging Sapi: Jurnal Surya Agritama Vol. 2 No. II. Edisi September 2013. Hal: 78 -88.

Tomek, W.G. dan Robindon, K.L., 1997. Agriculture Product Price Cornell. University Pres. London.

Walters, 2000. Fundamentals of Marketing. Edisi Ketujuh. ME.

Wedastra, M.S., 1996. Efisiensi Pemasaran Kedelai di Lombok Barat. Majalah Ilmiah. Kopertis Wilayah VII, Denpasar. 
Jurnal Peternakan Integratif Vol. 3 No. 2 : 155-166 